\title{
KONSEP INTEGRASI KEBIJAKAN PENGELOLAAN PERTAMBANGAN PERSPEKTIF PLURALISME HUKUM DI INDONESIA
}

\author{
Wahyu Nugroho \\ Fakultas Hukum Universitas Sahid Jakarta \& Kolegium Jurist Institute \\ Jl. Prof. Dr. Soepomo, SH. No. 84 Tebet, Jakarta Selatan 12870 \\ wahyulaw86@yahoo.com
}

\begin{abstract}
Management of mining resources is influenced by the plurality of these communities which have a legal system different from national law. In this conceptual idea, it has the urgency that it requires an integration of regulations and management policies in the mining sector. The problems studied are: first, what are the natural resource management policies in the mining sector in the context of legal pluralism? and second, how is the legal concept as an integrator in mining management policies in Indonesia? The conclusion is first, the policy of managing natural resources in the mining sector is dominated by state law, while there has been a marginalization of indigenous peoplesgroups in mining policies; and second, the legal concept can function as an integrator among the interests of sub-systems in mining management policies in Indonesia.
\end{abstract}

Keywords: Integration; Policy; Mining; Legal Pluralism

\begin{abstract}
Abstrak
Pengelolaan sumber daya pertambangan dipengaruhi oleh kemajemukan masyarakat tersebut yang memiliki sistem hukum berbeda dengan hukum nasional. Dalam gagasan konseptual ini memiliki urgensi bahwa dibutuhkannya suatu integrasi kebijakan pembentukan peraturan dan pengelolaan di bidang pertambangan. Permasalahan yang dikaji adalah: pertama, bagaimana kebijakan pengelolaan sumber daya alam di bidang pertambangan dalam konteks pluralisme hukum? dan kedua, bagaimana konsep hukum sebagai pengintegrasi dalam kebijakan pengelolaan pertambangan di Indonesia? Kesimpulannya adalah pertama, kebijakan pengelolaan sumber daya alam di bidang pertambangan didominasi hukum negara, sementara terjadi marginalisasi kelompok masyarakat hukum adat dalam kebijakan pertambangan; dan kedua, konsep hukum dapat berfungsi sebagai pengintegrasi diantara kepentingan sub sistem dalam kebijakan pengelolaan pertambangan di Indonesia.
\end{abstract}

Kata Kunci: Integrasi; Kebijakan; Pertambangan; Pluralisme Hukum

\section{A. Pendahuluan}

Kemajemukan masyarakat Indonesia sebagai identitas budaya bangsa dalam berinteraksi dengan sesama anggota masyarakat dan pemerintah dalam satu sistem, sangat mempengaruhi baik dalam pembuatan kebijakan maupun pelaksanaan kebijakan peraturan perundang-undangan yang melandaskan pada konstitusionalitas Undang-Undang Dasar Negara Republik
Indonesia Tahun 1945 (UUD 1945) pengelolaan sumber daya alam, maupun eksistensi masyarakat adat, beserta hak-hak yang melekat di dalamnya.

Dalam konteks kebijakan pembentukan peraturan di bidang pertambangan sebagai bagian dari kekayaan alam Indonesia, dipengaruhi oleh kemajemukan masyarakat tersebut yang memiliki sistem hukum berbeda dengan hukum nasional. 
Dibutuhkan suatu integrasi kebijakan pembentukan peraturan di bidang pertambangan dengan hak masyarakat adat atas sumber daya pertambangan, pola-pola pengelolaannya, dan kearifan lokal masyarakat dalam pengelolaan sumber daya pertambangan dan lingkungan hidup, agar kemajemukan masyarakat, sistem hukum dengan segala unsur-unsur didalamnya tetap terjaga.

Keberadaan Pasal 33 ayat (3) UUD 1945 tidak dapat dipisahkan dari Pembukaan UUD 1945. Hubungan antara hukum dan moral dapat ditemukan dalam rumusan tentang sila-sila dalam Pancasila. Mubyarto menyebutkan bahwa pada hakikatnya sila pertama dan sila kedua merupakan landasan moral, sila ketiga dan sila keempat merupakan cara atau metode kerja, dan sila kelima memuat tujuan akhir, yaitu keadilan sosial bagi seluruh rakyat Indonesia. Fungsi hukum adalah mewujudkan tujuan akhir tersebut, ialah sebesar-besar kemakmuran rakyat (Mubyarto, 1998). Dalam perjalanan kebijakan pertambangan nasional saat ini, kesejahteraan masyarakat, khususnya masyarakat hukum adat tidak dapat dirasakan karena secara politik hukum regulasi dan pelaksanaan kegiatan pertambangan tidak didukung oleh budaya hukum masyarakat hukum adat sebagai bagian dari karakter pluralisme hukum.

Bukanlah tanpa sebab bahwa yang dicita-citakan oleh para pendiri bangsa adalah masyarakat adil dan makmur. Kemakmuran tidak dapat dicapai jika tidak ada alokasi yang adil terhadap sumber daya alam. Alokasi yang adil adalah prasyarat untuk dapat terwujudnya sebesar-besar kemakmuran rakyat. Dengan demikian, jelaslah bahwa menentukan mana yang adil dan tidak atau kurang adil dan berdasarkan hal tersebut mengupayakan agar ketidakadilan dapat diminimalkan adalah pertimbangan moral yang didasarkan pada fakta yang ada, yakni bahwa modal dasar setiap orang tidak sama untuk memperoleh akses terhadap sumber daya alam (Sumardjono, 2014). Berbagai penelitian dan literatur berkaitan dengan kebijakan tambang hanya menggunakan pendekatan investasi, bisnis, dan keuntungan, sementara dalih negara atas penguasaan sumber daya alam sulit membuktikan adanya kesejahteraan masyarakat dari kegiatan pertambangan dalam konteks pluralisme hukum. Untuk dapat mencapai keadilan dengan mendasarkan pada pertimbangan moral, maka dibutuhkan sebuah hukum sebagai fungsi pengintegrasi diantara berbagai kepentingan yang ada.

Pertimbangan moral tersebut dilandasi oleh sila pertama dan sila kedua dari Pancasila. Adapun hukum, dalam hal ini peraturan perundang-undangan harus mampu mewujudkannya dalam rumusan peraturannya yang secara kontekstual taat pada prinsip umum untuk mencapai keadilan sebagaimana ditegaskan oleh Lon Fuller, bahwa negara sebagai organisasi yang mewakili seluruh rakyat diberi kewenangan untuk menguasai sumber daya alam, maka Mahkamah Konstitusi menjabarkan semangat itu ke dalam lima fungsi, yakni mengatur (regelendaad), membuat kebijakan (beleid), mengurus (bestuursdaad), mengelola (beheersdaad), dan mengawasi (toezichthoudendaad) agar distribusi sumber daya alam dijalankan secara adil (Redi, A; Prianto, Y and Sitabuana, 2017).

Dalam paper ini, permasalahan yang ingin dibahas sebagai gagasan konseptual adalah: pertama, bagaimana kebijakan pengelolaan sumber daya alam di bidang pertambangan dalam konteks pluralisme hukum?; dan kedua, bagaimana pengintegrasian selayaknya dilakukan atas pengelolaan pertambangan perspektif pluralisme hukum di Indonesia?

\section{B. Pembahasan}

\section{Politik Penguasaan Negara atas Sumber Daya Agraria dalam Konteks Pluralisme Hukum}

Hubungan hukum dengan tanah dan sumber daya agraria diatur dalam konstitusi Pasal 33 ayat (3) Undang-Undang Dasar Negara Republik Indonesia Tahun 1945, Undang-Undang Nomor 5 tahun 1960 
tentang Peraturan Dasar Pokok-Pokok Agraria, dan berbagai aturan sektoral berkaitan dengan pertanahan yang intinya menyatakan bahwa semua sumber daya agraria dikuasai oleh negara dan dipergunakan untuk sebesar-besarnya kemakmuran rakyat. Pengertian dikuasai oleh negara dimaknai sebagai kewenangan publik yang berarti bahwa Hak Menguasai Negara (HMN) sebagai bentuk hubungan hukum antara negara dengan sumber daya agraria adalah hubungan yang bersifat publik, bukan privat sebagaimana hubungan negara dengan sumber daya agraria pada pemerintahan kolonial dan pemerintahan feodal pada umumnya (Mahkamah Konstitusi, 2010).

Dalam kaitannya dengan wewenang penguasaan oleh negara, ditegaskan oleh Imam Soetignyo meliputi seluruh bumi, air, dan ruang angkasa di wilayah negara Republik Indonesia, baik yang: (1) diatasnya sudah ada hak-hak perorangan/keluarga, apapun nama hak itu; (2) diatasnya masih ada hak ulayat dan hak-hak semacam itu, apapun nama hak tersebut; dan (3) diatasnya tidak ada hak-hak tersebut sub a dan b, dan/atau sudah tidak ada lagi pemegang hak-hak tersebut (misalnya bekas tanah Swapraja, tanah bekas hak-hak barat, tanah hak bertuan, hutan negara, dan lain sebagainya (Sutignyo, 1990). Dengan demikian, penguasaan oleh negara yang disebut dengan hak menguasai negara merupakan hubungan hukum antara negara sebagai subyek dengan hak menguasai sumber daya alam dan sekaligus kewajiban bagi negara dalam penggunaan sumber daya alam tersebut yaitu untuk sebesar-besar kemakmuran rakyat. Dengan demikian, hak menguasai negara merupakan instrumen, sedangkan dipergunakannya untuk kemakmuran rakyat merupakan tujuan (objectives).

Penguatan konstitusional masyarakat hukum adat beserta hak-hak didalamnya, termasuk hak pengelolaan sumber daya alam, dalam hal ini pertambangan pada esensinya kegiatan usaha pertambangan tidak lepas dari konteks sosial lingkungan sekitar, termasuk kearifan masyarakat hukum adat, baik mulai dari pembentukan regulasi, penaatan yang terdiri dari sosialisasi instrumen perizinan, perizinan, pelaksanaan kegiatan usaha dan pengawasan, maupun penyelesaian konflik lingkungan hidup di kawasan pertambangan sangat berkaitan dengan masyarakat hukum adat. Semakin memperkuat asumsi dan dugaan penulis, bahwa pengakuan negara yang secara konstitusional sebagai norma dasar dalam UUD 1945, ternyata di dalam regulasi turunannya melalui kebijakan pertambangan nasional UU No. 4 tahun 2009 tentang Pertambangan Mineral dan Batubara terjadi inkonsistensi dengan ketidakberpihakan kepada kearifan masyarakat hukum adat, sehingga dalam praktik terjadi konflik dan tidak terintegrasinya pembangunan ekonomi melalui pengelolaan pertambangan dengan keadilan sosial dan keadilan ekologis.

Pluralisme hukum merupakan keberagaman hukum dalam suatu ikatan negara bangsa melalui sistem hukum nasional, dengan kondisi masyarakat dan kebudayaannya yang berbeda. Terdapat berbagai cara mengkaji pluralisme hukum, yakni: pertama, memetakan berbagai hukum yang ada dalam suatu bidang sosial, utamanya hukum negara dan non-negara; kedua, menjelaskan relasi, adaptasi, kompetisi antar sistem hukum; ketiga, pilihan individual warga memanfaatkan hukum tertentu ketika berkonflik; keempat, interaksi global, nasional, dan lokal yang memengaruhi interaksi antar hukum (Savitri, 2011).

Dalam hukum tanah nasional, terjadinya pluralisme hukum yang lemah (weak legal pluralism) ditandai dengan berlakunya UUPA dan berbagai peraturan pelaksanaannya sebagai hukum positif dalam bentuk hukum negara/nasional yang tertulis, di satu pihak, dan di pihak lain berlaku hukum adat, sebagai hukum positif yang pada umumnya tidak tertulis dan berlaku spesifik pada masing-masing daerah berlakunya hukum adat tersebut. Dominasi hukum Negara/hukum nasional (UUPA) 
sangat kuat terhadap hukum tanah adat (Nurlinda, 2009). Ketentuan di bidang agraria adalah beririsan dengan peraturan sektoral sumber daya alam dan ketentuan pengelolaan lingkungan hidup, sehingga dalam kebijakan pembentukan hukum maupun penerapannya, menggunakan optik kajian dan pendekatan pluralisme hukum.

Bandingkan juga dengan konsep pluralisme hukum diajukan oleh dua ahli, pertama, John Griffifth yang membagi pluralisme hukum lemah (weak legal pluralism) dan pluralisme hukum kuat (strong legal pluralism). Dikatakan pluralisme hukum lemah ketika negara mengakui hadirnya sistem-sistem lain di luar hukum negara, tetapi sistem-sistem hukum tersebut tunduk keberlakuannya di bawah hukum negara. sebaliknya, dikatakan pluralisme hukum kuat, ketika negara mengakui sistem-sistem hukum non-negara memiliki kapasitas keberlakuan yang sama kuatnya dengan hukum negara. Kedua, Sally Falk Moore, yang menurutnya konsep pluralisme hukum merujuk kepada situasi normatif yang heterogen, berdasarkan adanya fakta bahwa tindakan sosial selalu dilakukan dalam konteks bidang-bidang sosial yang beragam dan saling tumpang tindih (Irianto, 2005).

Konsep pluralisme hukum yang diklasifikasikan oleh Griffith, dikembangkan oleh para pengkaji sociolegal Indonesia, salah satunya Ricardo Simarmata. Pembedaan atas pluralisme hukum yang kuat (strong legal puralism) dan pluralisme hukum yang lemah (weak legal pluralism), didasarkan atas penggambaran situasi di lapangan. Pluralisme hukum yang kuat (strong legal pluralism) adalah situasi ketika antar berbagai sistem hukum melangsungkan interaksi yang tidak saling mendominasi (sederajat). Sistem hukum yang satu tidak lebih superior dibandingkan sistem hukum yang lain. Masyarakat tidak hanya tunduk pada sistem hukum negara/nasional, tetapi juga tunduk pada sistem hukum lainnya (biasanya hukum adat/lokal) (Simarmata, 2009).
Sebaliknya dalam pluralisme hukum yang lemah (weak legal pluralism) terjadi pada situasi dimana salah satu sistem hukum (biasanya disebut negara), memiliki posisi superior dihadapan sistem hukum lainnya (biasanya sistem hukum lokal/adat) yang sama-sama berlaku. Dalam pluralisme hukum yang lemah (weak legal pluralism), individu atau kelompok lebih sering menggunakan salah satu sistem hukum, baik karena atas dasar kesadaran hukumnya ataupun karena tekanan pihak tertentu.

John Griffiths mengatakan proses penerimaan formal negara terhadap pluralisme hukum "lemah" semakin menambah keruwetan sistem hukum negara yang pada dasarnya menginginkan adanya keseragaman. Banyak pihak yang menganggap kompleksitas yang ditimbulkan oleh pluralisme hukum "lemah" ini sebagai bentuk kecacatan sistem hukum negara. Pluralisme hukum "lemah" merupakan suatu konsep carut marut yang diciptakan oleh ideologi sentralisme hukum sebagai bentuk kompromi terhadap adanya berbagai pembangkangan yang dilakukan oleh realitas sosial terhadapnya. Menurut para pengusung ideologi sentralisme hukum, upaya membentuk suatu sistem hukum modern yang seragam memerlukan adanya pengecualian-pengecualian melalui pemberlakuan sistem hukum adat tertentu yang dilakukan dalam suatu proses "pembentukan bangsa" (nation building), sampai pada suatu saat dimana masyarakat primitif dan heterogen yang masih tersisa melebur menjadi masyarakat yang homogen dan "modern" (Griffiths, 2005).

Dalam disertasi Satjipto Rahardjo yang dikembangkan sebuah buku berjudul hukum dan perubahan sosial, suatu tinjauan teoritis serta pengalaman-pengalaman di Indonesia, menggunakan teori Talcott Parsons tentang sub sistem beserta fungsi primernya yang didalamnya memiliki fungsi integrasi (Rahardjo, 2009). Parsons menjelaskan bahwa tindakan individu ditempatkan dalam kerangka suatu sistem yang besar dan terbagi ke dalam sub sistem-sub sistem, diantaranya sub sistem sosial dengan fungsi 
primernya integrasi, sub sistem budaya dengan fungsi primernya mempertahankan pola, sub sistem kepribadian dengan fungsi primernya mencari tujuan, sedangkan sub sistem organisme kelakuan dengan fungsi primernya adaptasi.

Hukum sebagai fungsi pengintegrasi yang digagas oleh Parsons, menurut penulis tidak berbeda jauh dengan terminologi perpaduan antara prinsip-prinsip yang bersumber dari nilai sosial modern dan tradisional atau kearifan lokal secara selektif dalam istilah Riggs sebagai hukum prismatik, sebagaimana yang dikembangkan oleh Nurhasan Ismail dalam pidato pengukuhan Guru Besar Fakultas Hukum Universitas Gajah Mada dikatakan bahwa:

"Jika hukum Indonesia diinginkan tidak
menjadi instrumen pendorong terjadinya kemiskinan, penutupan akses bagi kelompok yang lemah, kesenjangan penguasaan sumber daya yang tersedia, dan konflik struktural, perubahan politik pembangunan hukum tampaknya menjadi sebuah keniscayaan dengan mendasarkan pada kemajemukan masyarakat indonesia. Masyarakat majemuk ditandai diantaranya adalah: Pertama, adanya kelompok-kelompok yang berbeda dengan nilai sosial yang berbeda, yaitu tradisional atau modern atau keduanya sebagai pedoman berperilaku; kedua, adanya perbedaaan tingkat kemampuan dari kelompok-kelompok yang berbeda untuk beradaptasi terhadap kondisi sosial, ekonomi, dan politik yang dicitacitakan bersama; ketiga, adanya perbedaan orientasi kepentingan diantara kelompok-kelompok yang berbeda, yaitu antara individual dan kolektivitas dengan konsekuensi yang berbeda terhadap perebutan akses dan sumber daya (Ismail, 2011).

Benda Beckmann sebagaimana yang dikutip oleh Lidwina Inge Nurtjahyo, mengatakan bahwa pertemuan antar sistem hukum negara dengan sistem hukum adat atau sistem hukum lainnya sangat berperan dalam memberi pemahaman baru kepada akademisi hukum, praktisi hukum maupun penggiat advokasi hak-hak masyarakat di berbagai bidang terhadap kondisi keberagaman hukum dalam masyarakat Indonesia yang pluralistik. Kajian ini menyadarkan bahwa sebetulnya hukum negara bukan berdiri, melainkan pada konteks-konteks tertentu berinteraksi bahkan berkompetisi dengan sistem-sistem hukum lain yang telah ada lebih dulu dalam masyarakat (Nurtjahyo, 2011).

Kebijakan pertambangan nasional yang lebih dominan dengan sub sistem modern dengan masyarakat adat yang kental dengan nilai-nilai kearifan lokal atau nilai sosial tradisional sangat penting untuk diintegrasikan. Dalam perjalanan mulai lahirnya Undang-Undang Nomor 4 Tahun 2009 tentang Pertambangan Mineral dan Batubara hingga saat ini telah menimbulkan pertentangan, konflik sosial atau sengketa baik pada saat penetapan wilayah pertambangan, perizinan, tumpang tindih sektor perkebunan atau kehutanan, maupun kegagalan dalam mengelola limbah atau secara sengaja menimbulkan pencemaran dan atau kerusakan lingkungan akibat adanya kegiatan usaha pertambangan. Untuk memperbaikinya, perlu dilakukan integrasi di antara dua sub sistem hukum modern dengan sub sistem hukum tradisional.

Pluralisme hukum atau kemajemukan antar sub sistem hukum dalam bingkai Negara Kesatuan Republik Indonesia menjadi suatu keniscayaan dan tidak perlu dipertentangkan dengan unifikasi, sehingga bagaimana nilai-nilai yang pluralis di masyarakat atau dalam masyarakat adat diakomodasi ke dalam kebijakan pertambangan nasional dalam kerangka unifikasi hukum pertambangan nasional khususnya dan hukum sumber daya alam pada umumnya. 


\section{Pengintegrasian Pengelolaan Perspektif Pluralisme Hukum di Indonesia}

Hukum sebagai fungsi pengintegrasi diantara kepentingan-kepentingan para pemangku kepentingan dalam kebijakan pertambangan nasional diantaranya pembentuk undang-undang, pemerintah daerah, korporasi, kelompok masyarakat sipil dan masyarakat baik dalam konteks peran serta dalam proses pembentukan hukum dan kebijakan di bidang pertambangan, maupun dalam tataran praksis operasional pengelolaan usaha pertambangan. Kebijakan pertambangan sarat dengan kepentingan diantara pemangku kepentingan hingga masyarakat, sehingga perlu diintegrasikan guna memayungi kepentingan tersebut dan kompleksitas sub sistem dalam masyarakat.

Dalam perspektif Mochtar Kusumaatmadja, pembaruan hukum dapat dilakukan melalui kebijakan pembentukan regulasi di bidang pertambangan yang partisipatif dan responsif sesuai dengan kebutuhan masyarakat, termasuk komunitas masyarakat hukum adat yang memiliki filosofi pengelolaan lingkungan hidup secara lokal.

Analisis dasar Kurnia Warman bahwa terdapat 4 (empat) syarat yang harus dipenuhi agar hukum adat dan hukum negara dapat bekerjasama dalam pengaturan agraria dan sumber daya alam, yaitu: pertama, keterbukaan sistem hukum adat terhadap pengaruh dari luar; kedua, pengakuan hukum Negara terhadap eksistensi hukum adat; ketiga, kemauan politik pemerintah untuk mengakomodasi nilai-nilai yang terkandung dalam hukum adat dalam pelaksanaan pembangunan; dan keempat, desentralisasi pengaturan agraria dan sumber daya alam. Analisis tersebut digunakan oleh Ida Nurlinda dengan sebagian mengkonfirmasi bahwa tidak adanya kemauan politik pemerintah dalam mengakomodasi hukum adatdalam pelaksanaan pembangunan (Nurlinda, 2014).
Permasalahan akses dalam konteks pengelolaan sumber daya pertambangan mineral dan batubara perlu didudukkan bersama, diintegrasikan kepentingan yang sama para stakeholders untuk melakukan pengelolaan pertambangan, baik pemerintah, swasta (korporasi), maupun masyarakat adat/lokal. Kelompok masyarakat sipil, dan termasuk didalamnya kesatuan masyarakat hukum adat telah mulai bergerak dinamis dengan cara pandang, sikap, dan umpan balik kepada pemerintah dan korporasi (swasta), sehingga perubahan cara berpikir dan sikap-sikap kelompok masyarakat tersebut semakin memahami hak-hak konstitusional warga negara, keadilan sosial dan keadilan ekologis. Legalisasi negara terhadap masyarakat hukum adat diakui keberadaannya, akan tetapi untuk mendapatkan legalisasi tersebut, harus juga mengikuti prosedur atau aturan main yang telah ditentukan oleh negara melalui peraturan.

Dalam konteks integrasi kebijakan pertambangan nasional dengan masyarakat (masyarakat adat), secara hierarkhi peraturan perundang-undangan, negara telah mengakui keberadaan masyarakat hukum adat, namun yang menjadi permasalahan adalah komitmen (political will) dari pemerintah, khususnya pemerintah daerah untuk mengakomodasi nilai-nilai yang terkandung dalam hukum adat dalam pelaksanaan pembangunan kegiatan usaha pertambangan. Lahirnya kebijakan pertambangan nasional justru memunculkan konflik-konflik baik vertikal maupun horisontal antara sesama masyarakat terkait akses pengelolaan sumber daya pertambangan.

Achmad Sodiki mempertegas dalam kaitannya dengan peran negara yang mendominasi sebagai bagian dari perkembangan proses politik atas segala segi kehidupan masyarakat nasional sudah menjadi kenyataan. Keadaan sudah berubah sehingga kewenangan negara dikontrol dan diawasi secara lebih ketat, telah pula dibuat pasal-pasal amandemen UUD 1945 yang memperkuat kedudukan masyarakat hukum 
adat, misalnya pasal-pasal yang mengakui dan menghormati eksistensi masyarakat hukum adat dan hak-hak tradisionalnya (Pasal 18B ayat 2), hak untuk hidup mempertahankan hidup dan kehidupan (Pasal 28A, hak untuk hidup sejahtera dan mempunyai tempat tinggal (Pasal $28 \mathrm{H}$ ayat 1), perlindungan hak milik (Pasal 28H ayat 4). Pengakuan dan penghormatan terhadap kesatuan-kesatuan masyarakat hukum adat dan hak-hak tradisionalnya justru diperintahkan untuk diatur dalam undangundang, sehingga kekuatan hukumnya lebih kuat daripada dengan Peraturan Pemerintah atau Keputusan Presiden (Sodiki, 2013).

Pengelolaan sumber daya pertambangan dalam kebijakan dan regulasinya masih mengenyampingkan kesatuan masyarakat hukum adat, beserta hak-hak tradisional dan pengelolaannya. Kelompok komunitas tradisional tersebut secara konstitusionalitas dan peraturan perundang-undangan turunannya telah memiliki legitimasi yang kuat, sehingga bagaimana kebijakan pertambangan mampu mengintegrasikan semua kepentingan yang ada. Kepentingan yang terejawantahkan dalam hak-hak ekonomi, hak sosial, hak budaya, hak tradisional, hak bertempat tinggal, serta hak untuk mendapatkan lingkungan hidup yang baik dan sehat diintegrasikan ke dalam kebijakan (legal policy) pengaturan di bidang pertambangan dalam rangka pembaruan hukum lingkungan di sektor pertambangan mineral dan batubara. Mencermati karakter hukum yang terdapat pada hubungan hukum dengan tanah dan bahan tambang penting dilakukan ketika kenyataan menunjukkan bahwa pemberian kedua hubungan hukum itu dapat terjadi di atas ruang atau di lokasi yang sama (Sitorus, 2016).

Pelimpahan hak menguasai Negara (HMN) atas sumber daya alam pada otoritas pertambangan melahirkan kewenangan untuk menetapkan wilayah pertambangan (WP) atas sumber daya alam berupa mineral dan batubara. Wilayah pertambangan terbagi atas Wilayah Usaha Pertambangan (WUP), Wilayah Pertambangan Rakyat (WPR), dan
Wilayah Pencadangan Negara (WPN). Kewenangan untuk menetapkan "wilayah" otoritas pertambangan tersebut merupakan wewenang yang berkarakter publik, yaitu wewenang untuk melakukan pengaturan dalam penggunaan dan pemanfaatan sumber daya alam berupa tambang (Sembiring, 2016).

Perbedaan cara pandang masyarakat adat dan negara terhadap sumber daya alam, khususnya pertambangan menjadi penyebab utamanya terjadi tarik menarik kepentingan dan gesekan, sehingga hal tersebut yang perlu diintegrasikan semua kepentingan yang ada. Cara pandang juga berkaitan dengan dasar cara berfikir atau paradigma yang secara garis besar diklasifikasikan oleh Eko Cahyono dalam pengelolaan sumbersumber agraria, yakni pertama, paradigma pembangunan dan ekonomi dengan mengejar pertumbuhan dan efisiensi; kedua, paradigma politik sumber daya alam yang juga terbagi lagi ke dalam tiga pandangan, konservasionistik, developmentalistik, dan eko-populis; dan ketiga, paradigma kemiskinan dan kesejahteraan yang melihat masalah kemiskinan bersifat struktural, kultural, atau kombinasi keduanya. Dominasi paradigma developmentalistikpositivistik dalam pengelolaan sumber daya agraria melahirkan beragam kebijakan yang cenderung mendahulukan pertumbuhan dan keuntungan ekonomi investor (Cahyono, 2017).

Integrasi atau fungsionalisme struktural banyak di ranah ilmu sosial yang dikembangkan oleh Talcott Parsons, Kingsley Davis, dan Robert K. Merton. Dalam perspektif ini masyarakat dilihat sebagai suatu jaringan kelompok yang bekerja sama secara terorganisasi dalam suatu cara yang teratur menurut seperangkat norma dan nilai yang dianut oleh sebagian besar masyarakat tersebut. Dengan demikian dalam pandangan ini, masyarakat pada dasarnya terintegrasi oleh adanya kesepakatan tentang nilai-nilai tertentu yang dijunjung tinggi secara bersama oleh sebagian besar warga masyarakat yang bersangkutan. Masyarakat juga dipandang 
sebagai sistem yang secara fungsional terintegrasi ke arah terwujudnya keseimbangan atau equilibrium. Oleh karena itu pendekatan integrasi juga disebut sebagai pendekatan equilibrium (Sunarto, 2015).

Dalam konteks kebijakan pertambangan yang berkarakter pluralisme hukum, integrasi sebagai pendekatan equilibrium merupakan konsep yang harus dikembangkan dalam kerangka unifikasi hukum sumber daya alam di bidang pertambangan. Pengintegrasian kebijakan pengelolaan pertambangan perspektif pluralisme hukum di Indonesia dilakukan guna memayungi kepentingan tersebut dan kompleksitas sub sistem dalam masyarakat, yakni akomodasi kepentingan sosial, budaya, dan lingkungan masyarakat hukum adat yang merupakan akar budaya bangsa, beserta filosofinya dalam pengelolaan lingkungan hidup.

\section{Simpulan}

Kebijakan pengelolaan sumber daya alam di bidang pertambangan dalam konteks pluralisme hukum dalam bingkai Negara Kesatuan Republik Indonesia menjadi suatu keniscayaan dan tidak perlu dipertentangkan dengan unifikasi, sehingga bagaimana nilainilai yang pluralis di masyarakat atau dalam masyarakat adat diakomodasi ke dalam kebijakan pertambangan nasional dalam kerangka unifikasi hukum pertambangan nasional khususnya dan peraturan sektoral sumber daya alam lainnya.

Pengintegrasian kebijakan pengelolaan pertambangan perspektif pluralisme hukum di Indonesia dilakukan guna memayungi kepentingan tersebut dan kompleksitas sub sistem dalam masyarakat, yakni akomodasi kepentingan sosial, budaya, dan lingkungan masyarakat hukum adat yang merupakan akar budaya bangsa, beserta filosofinya dalam pengelolaan lingkungan hidup.

\section{DAFTAR PUSTAKA}

Cahyono, E. (2017). Gemah Ripah Loh Jinawi, Untuk Siapa?: Makin Jauhnya Cita-Cita Kedaulatan Agraria. Jurnal
Kajian Ruang Sosial-Budaya, Vol. 1 (No. 1), Pp. 70-72., 1(1), 70-72.

Griffiths, J. (2005). Pluralisme Hukum: Sebuah Pendekatan Interdisipliner. Jakarta: Penerbit Perkumpulan untuk Pembaharuan Hukum Berbasis Masyarakat dan Ekologis (HuMa).

Irianto, S. (2005). Sejarah Pluralisme Hukum dan Konsekuensi Metodologisnya. In Pluralism Hukum: Sebuah Pendekatan Interdisipliner. Jakarta: Huma.

Ismail, N. (2011). Hukum Prismatik: Kebutuhan Masyarakat Majemuk Sebuah Pemikiran Awal, Pidato Pengukuhan Jabatan Guru Besar pada Fakultas Hukum Universitas Gadjah Mada. Yogyakarta.

Mahkamah Konstitusi. (2010). Naskah Komprehensif Perubahan UndangUndang Dasar Negara Republik Indonesia Tahun 1945, Latar Belakang, Proses, dan Hasil Pembahasan 19992002, Buku VII, Keuangan, Perekonomian Nasional, dan Kesejahteraan Sosial, Edisi Revisi. Jakarta: Mahkamah Konstitusi.

Mubyarto. (1998). Reformasi Sistem Ekonomi dari Kapitalisme Menuju Ekonomi Kerakyatan,. Yogyakarta: Aditya Media.

Nurlinda, I. (2009). Prinsip-Prinsip Pembaruan Agraria Perspektif Hukum. j: Rajawali Press.

Nurlinda, I. (2014). Monograf Hukum Agraria Membangun Pluralisme Hukum dalam Kerangka Unifikasi Hukum Agraria. Bandung: Pusat Studi Hukum Lingkungan dan Penataan Ruang Fakultas Hukum Universitas Padjadjaran \& Logoz Publishing.

Nurtjahyo, L. (2011). Menelusuri Perkembangan Kajian Pluralisme Hukum di Indonesia. In Untuk Apa Pluralisme Hukum? Konsep, Regulasi, Negosiasi dalam Konflik Agraria di Indonesia. Jakarta: Epistema. 
Rahardjo, S. (2009). Hukum dan Perubahan Sosial, Suatu Tinjauan Teoritis serta Pengalaman-Pengalaman di Indonesia. Yogyakarta: Genta Publishing.

Redi, A; Prianto, $\mathrm{Y}$ and Sitabuana, T. (2017). Konstitusionalitas Hak Masyarakat Hukum Adat atas Hak Ulayat Rumpon di Provinsi Lampung. Jurnal Konstitusi, 14(3), 466-467.

Savitri, M. (2011). Untuk Apa Pluralisme Hukum? Konsep, Regulasi, Negosiasi dalam Konflik Agraria di Indonesia. Jakarta: Epistema Institute-HuMAForest Peoples Programme.

Sembiring, J. (2016). Hak Menguasai Negara atas Sumber Daya Agraria. Bhumi Jurnal Agraria Dan Pertanahan, 2(2), 128.

Simarmata, R. (2009). Mencari Karakter Aksional dalam Pluralisme Hukum, Jakarta:. In Pluralisme Hukum: Sebuah Pendekatan Interdisipliner. Jakarta: HuMa dan Ford Foundation.
Sitorus, O. (2016). Penataan Hubungan Hukum dalam Penguasaan, Pemilikan, Penggunaan, dan Pemanfaatan Sumber Daya Agraria (Studi Awal terhadap Konsep Hak atas Tanah dan Izin Usaha Pertambangan). Bhumi Jurnal Agraria Dan Pertanahan, 2(1), 6.

Sodiki, A. (2013). Politik Hukum Agraria. Jakarta: Konstitusi Press.

Sumardjono, M. (2014). Mewujudkan Semangat Konstitusi dalam Pembentukan Undang-Undang di Bidang Sumber Daya Alam, dalam Pendulum Antinomi Hukum, Antologi 70 Tahun Valerine J. L. Kriekhoff. Yogyakarta: Genta Publishing.

Sunarto. (2015). Hukum dalam Perspektif Teori Integrasi dan Teori Konflik. Jurnal INTEGRALISTIK, 1(1), 49.

Sutignyo, I. (1990). Politik Agraria Nasional, Hubungan Manusia dan Tanah yang Berdasarkan Pancasila. Yogyakarta: Gadjah Mada University Press. 